An anomalous behavior in degraded bulk heterojunction organic solar cells

This article has been downloaded from IOPscience. Please scroll down to see the full text article.

2011 Phys. Scr. 84065803

(http://iopscience.iop.org/1402-4896/84/6/065803)

View the table of contents for this issue, or go to the journal homepage for more

Download details:

IP Address: 202.41.10.242

The article was downloaded on 16/02/2012 at 10:35

Please note that terms and conditions apply. 


\title{
An anomalous behavior in degraded bulk heterojunction organic solar cells
}

\author{
Vinamrita Singh ${ }^{1}$, Swati Arora ${ }^{2}$, Pankaj Kumar ${ }^{3}$, \\ Pramod Kumar Bhatnagar ${ }^{4}$, Manoj Arora ${ }^{5}$ and Ram Pal Tandon ${ }^{1}$ \\ ${ }^{1}$ Department of Physics and Astrophysics, University of Delhi, Delhi 110007, India \\ ${ }^{2}$ Department of Physics, Zakir Husain College, University of Delhi, Delhi 110002, India \\ ${ }^{3}$ National Physical Laboratory, New Delhi 110012, India \\ ${ }^{4}$ Department of Electronic Science, University of Delhi South Campus, Delhi 110021, India \\ ${ }^{5}$ Department of Physics, Ramjas College, University of Delhi, Delhi 110007, India \\ E-mail: drswatia@yahoo.com
}

Received 5 July 2011

Accepted for publication 14 October 2011

Published 8 November 2011

Online at stacks.iop.org/PhysScr/84/065803

\begin{abstract}
An anomalous behavior-a change in polarity with the passage of time in the bulk heterojunction poly(3-hexylthiophene) (P3HT):6,6-phenylC61 butyric acid methyl ester (PCBM) organic solar cells-is reported here. This work is a continuation of our previous work where the initial degradation of the organic solar cells, freshly prepared up to $4 \mathrm{~h}$, was mainly due to domain formation in the active layer. With the passage of time, the activity at the interfaces starts becoming significant. A decrease of $V_{\mathrm{OC}}$ and $J_{\mathrm{SC}}$, leading to a change in polarity, has been reported and explained up to $300 \mathrm{~h}$ after fabrication.
\end{abstract}

PACS numbers: 81.05.ub, 81.05.Lg

(Some figures in this article are in colour only in the electronic version.)

\section{Introduction}

The low efficiency, short shelf life and poor stability of organic solar cells are the main reasons why these devices have not been commercialized yet. Although the reported efficiency is about 6-8\% [1, 2], degradation is the main problem. Therefore, the primary aim is to check the degradation process, and for that purpose it is essential to find the mechanisms responsible for the degradation. A number of researchers have pointed out qualitatively various degradation mechanisms [3-7]. We believe that the rate of degradation and the responsible dominant mechanism are different for different structures, and there is a need to identify them. Life spans of bulk heterojunctions are very likely dominated by the formation of interface states, the rate of interfacial charge transfer and the shift in the Fermi level [8]. In this paper, the interface/surface states and shift in the Fermi level (pseudo Fermi level) [9] are mainly held responsible for the observed degradation.

The properties of the interface between the various layers and electrodes are responsible for shaping the $J-V$ characteristics. It has been reported that the dipole formed at the interface, the work function of the electrodes (anode and cathode) and the energy level (highest occupied molecular orbital (HOMO)-lowest unoccupied molecular orbital (LUMO)) of the organic material contribute significantly to $J-V$ characteristics $[10,11]$.

Our previous work [12] showed that during the initial degradation (freshly prepared up to $4 \mathrm{~h}$ ) there is insignificant change in open circuit voltage $V_{\mathrm{OC}}$ and a significant change in short circuit current, $J_{\mathrm{SC}}$. This is because of the growth in size of domains, leading to an increase in the surface area and hence a decrease in $J_{\mathrm{SC}}$. When the cells were studied beyond $4 \mathrm{~h}$ up to $300 \mathrm{~h}$ after fabrication, it was found that there was a significant decrease in both $V_{\mathrm{OC}}$ and $J_{\mathrm{SC}}$. The degradation continued and cells showed a change in polarity a few hours after fabrication.

\section{Experimental details}

Various solar cell structures were prepared on patterned indium tin oxide (ITO) glass $\left(18 \Omega \mathrm{sqr}^{-1}\right)$ using the technique reported in our work [12]. Patterned ITO-coated glass substrates were ultrasonicated in soap solution and cleaned 
thoroughly with distilled water to remove the soap. The substrates were then cleaned by boiling in acetone for $15 \mathrm{~min}$, followed by similar cleaning in trichloroethylene and isopropanol. The substrates were dried in a vacuum oven at $120^{\circ} \mathrm{C}$ for $30 \mathrm{~min}$. Finally, the substrates were exposed to oxygen plasma for $5 \mathrm{~min}$ to increase the surface wettability. PEDOT:PSS was spin coated at $2000 \mathrm{rpm}$ for $2 \mathrm{~min}$ on the substrates. The samples were annealed at $100^{\circ} \mathrm{C}$ for $15 \mathrm{~min}$ in a vacuum oven. To prepare the active layer, a solution of poly(3-hexylthiophene) (P3HT):6,6-phenylC61 butyric acid methyl ester (PCBM) ( $1: 1$ ratio by weight) was taken in chlorobenzene and spin coated at $1000 \mathrm{rpm}$ for $2 \mathrm{~min}$ to form a $\sim 170 \mathrm{~nm}$ thick layer. The samples were finally annealed at $120{ }^{\circ} \mathrm{C}$ for $15 \mathrm{~min}$. In all these structures, the $\mathrm{Al}$ electrodes were thermally evaporated in vacuum of $4 \times 10^{-6}$ torr. The following structures were fabricated and studied:

\begin{tabular}{|c|c|c|}
\hline S1 & $\begin{array}{l}\text { Glass/ITO/PEDOT:PSS/ } \\
\text { P3HT:PCBM/Al }\end{array}$ & without $\mathrm{LiF}$ \\
\hline S2 & Glass/PEDOT:PSS/P3HT:PCBM/Al & $\begin{array}{l}\text { without ITO } \\
\text { and without } \mathrm{LiF}\end{array}$ \\
\hline S3 & Glass/ITO/P3HT:PCBM/Al & $\begin{array}{l}\text { without } \\
\text { PEDOT:PSS and } \\
\text { without LiF }\end{array}$ \\
\hline S4 & $\begin{array}{l}\text { Glass/ITO/PEDOT:PSS/ } \\
\text { P3HT:PCBM/LiF/Al }\end{array}$ & with $\mathrm{LiF}$ \\
\hline S5 & $\begin{array}{l}\text { Glass/PEDOT:PSS/P3HT:PCBM/ } \\
\text { LiF/Al }\end{array}$ & $\begin{array}{l}\text { without ITO } \\
\text { and with LiF }\end{array}$ \\
\hline S6 & Glass/ITO/P3HT:PCBM/LiF/Al & $\begin{array}{l}\text { without } \\
\text { PEDOT:PSS and } \\
\text { with LiF }\end{array}$ \\
\hline
\end{tabular}

The photovoltaic characterization of all the uncapsulated devices was carried out under illuminated conditions using a solar simulator SS50AAA with $100 \mathrm{~mW} \mathrm{~cm}^{-2}$ power intensity. The organic solar cells were illuminated from the ITO side and current-voltage characteristics were measured using a Keithley 2400 source meter unit. The cells were not under constant illumination and were exposed to light only when the measurements were carried out. The measurements for all the devices were carried out one by one immediately after deposition and then all the devices were stored under the same clean room environmental conditions (under normal atmospheric pressure and temperature). The $J-V$ measurements on these devices were carried out at regular time intervals up to $300 \mathrm{~h}$ after fabrication.

\section{Results and discussions}

Figures 1(a)-(f) show normalized $V_{\mathrm{OC}}$ and $J_{\mathrm{SC}}$ with time obtained from figures $1(\mathrm{~g})$ and $(\mathrm{h})$ shown for all the structures. It can be seen that in all the structures both $V_{\mathrm{OC}}$ and $J_{\mathrm{SC}}$ show a change of polarity with time. For each cell, the time of change in polarity is found to be different for different structures as shown in table 1.

During ageing, the following factors contribute:

- Degradation of electrodes, ITO and Al

- Degradation due to a change in the active polymer layer

- Degradation due to exposure of PEDOT:PSS to moisture
- Degradation due to changes at ITO/PEDOT:PSS, PEDOT:PSS/P3HT:PCBM and P3HT:PCBM/Al interfaces.

The net effect can be physically explained in terms of the following:

- Shifting in HOMO-LUMO level of polymer blend

- Changes in the work function of ITO and Al.

The results are best explained with the help of proposed mechanisms shown schematically in figures 2(a)-(c). Figure 2(a) presents the band diagram of a freshly prepared P3HT:PCBM blend solar cell. Figure 2(b) shows the band diagram after donor-acceptor domain formation sets in during initial degradation, whereas figure 2(c) shows the proposed modified energy levels for long-hour (beyond $40 \mathrm{~h}$ ) degradation. The degradation may be attributed to a shift in HOMO-LUMO level by introduction/diffusion of impurities such as $\mathrm{Al}$ and In or their corresponding cations [13, 14], molecules of $\mathrm{O}_{2}$ and $\mathrm{H}_{2} \mathrm{O}$ [4]. We believe that the interlayer formation at various interfaces introduces interface states, resulting in a change in HOMO-LUMO of the active layer and the work function of electrodes. The interface states may also be introduced due to other factors such as (i) moisture/oxygen, (ii) chemical reaction at the interface and (iii) impurities. The shift of various energy levels, upward or downward, depends on the interface and the interfacial dipole changes [10]. The change in $\mathrm{Al}$ work function to $-3.3 \mathrm{eV}$ is approximately the same as that reported by Toyoshima et al [9]. The work function of ITO can vary from -4.3 to -5.1 depending on the stoichiometry, organic contamination and oxidation type [15], and we have assumed it to be shifting to about $-5.0 \mathrm{eV}$ and this explains our experimental behavior. Further, approximate changes in HOMO-LUMO levels in the active material have been shown in figure 2(c). It is clear from figure 2(c) that there is a good probability of movement of hole from modified P3HT HOMO $(-5 \mathrm{eV})$ to a pseudo work function level of $\mathrm{Al}(-3.3 \mathrm{eV})$. The origin of the pseudo work function is the introduction of interface states generated through chemical interaction between active material and the electrode [9]. Similarly, on the other hand, the electrons have a probability to reach ITO through PEDOT:PSS. Under this situation the $\mathrm{Al}$ electrode will become positive and the ITO electrode will become negative, i.e. a change of polarity with time. The situation in figure 2(c) will arrive at different times for different structures, depending on the nature of active layer/interface and therefore the time of change of polarity will also vary as shown in table 1 . As an example of $\mathrm{S} 1$ (without $\mathrm{LiF}$ ) the degradation is very slow but when the structure is modified by putting $\mathrm{LiF}$ (S4) between the active layer and aluminum, the current improves slightly but the cell degrades fast, leading to a change in polarity after about $170 \mathrm{~h}$ after fabrication. This may be attributed to the fast degradation of $\mathrm{LiF} / \mathrm{Al}$ electrode. The same argument can be given for S2 and S5 that are without ITO. The cells without ITO are not good because the current density is very small. Here also the change in polarity can be explained on the basis of figure 2(c) discussed above. Similarly, in S3 and S6 the degradation is very fast, because of which the situation shown in figure $2(\mathrm{c})$ is reached very fast $(\sim 40 \mathrm{~h})$. The removal of PEDOT:PSS is not a good choice in making a solar cell 


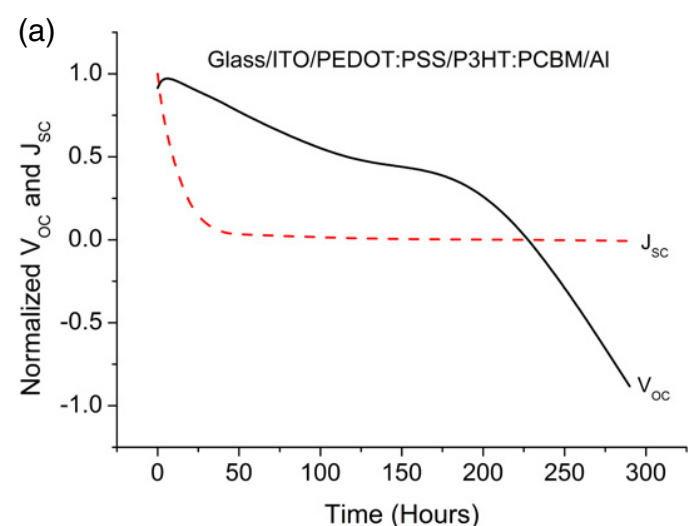

(c)
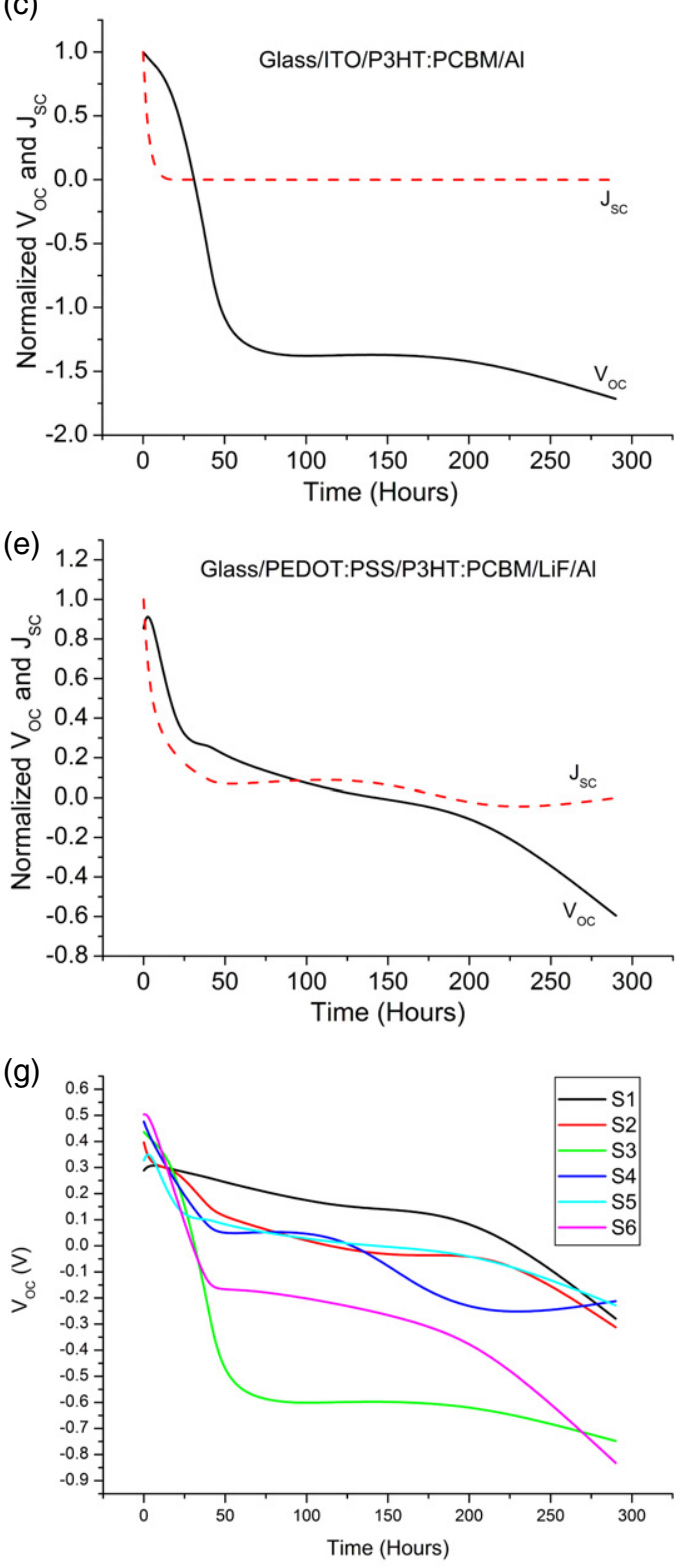

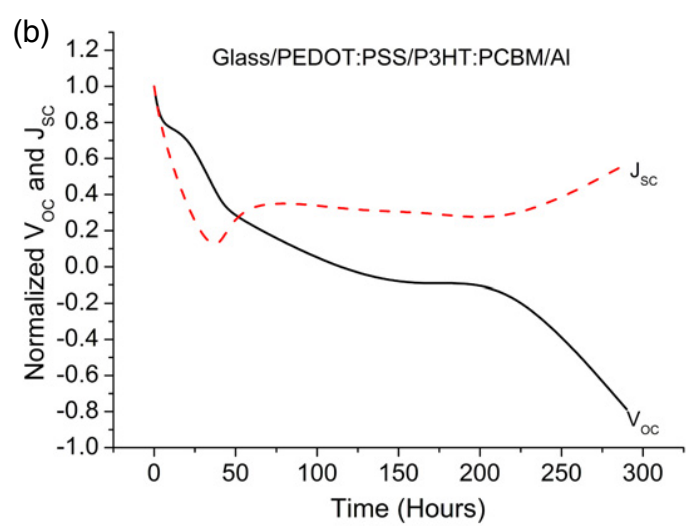

(d)
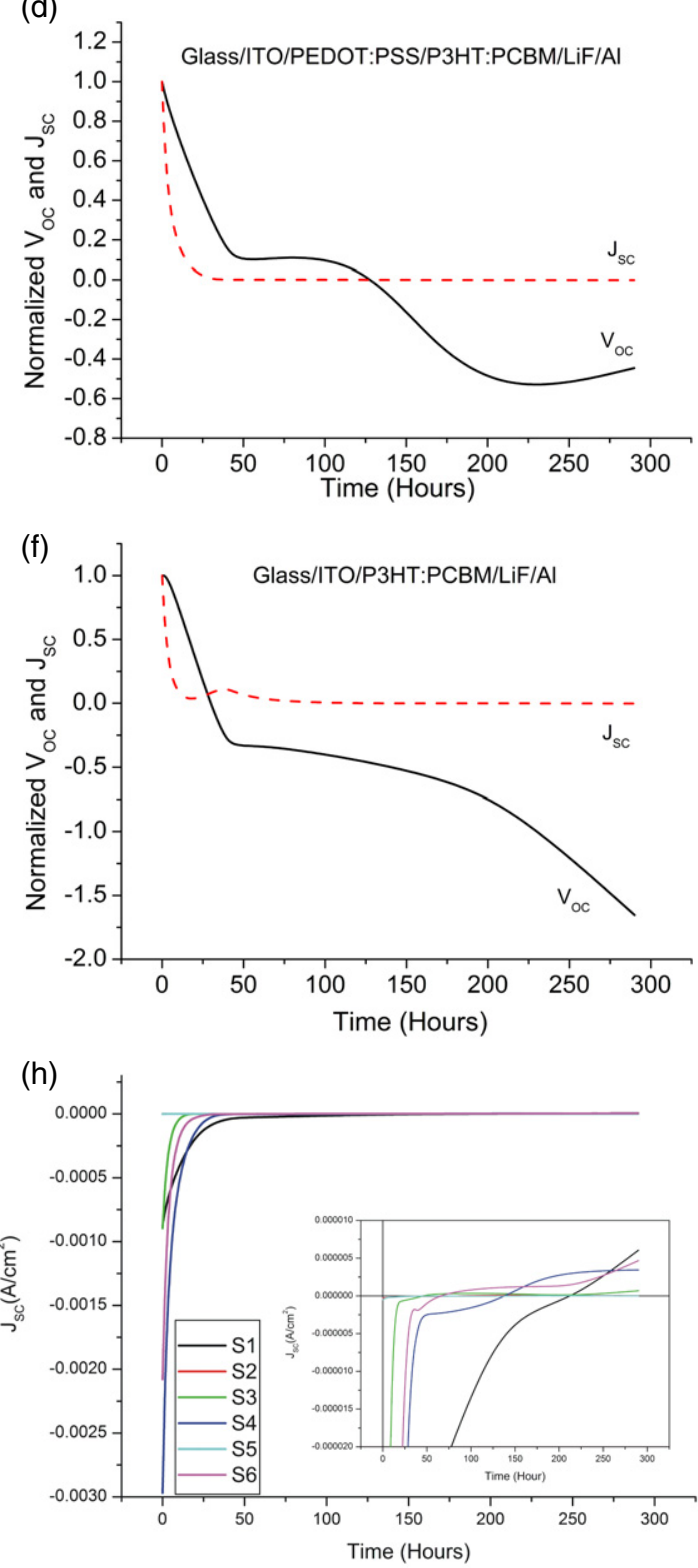

Figure 1. (a) Variation of normalized $V_{\mathrm{OC}}$ and $J_{\mathrm{SC}}$ for uncapsulated glass/ITO/PEDOT:PSS/P3HT:PCBM/Al as a function of time. (b) Variation of normalized $V_{\mathrm{OC}}$ and $J_{\mathrm{SC}}$ for uncapsulated glass/PEDOT:PSS/P3HT:PCBM/Al as a function of time. (c) Variation of normalized $V_{\mathrm{OC}}$ and $J_{\mathrm{SC}}$ for uncapsulated glass/ITO/P3HT:PCBM/Al as a function of time. (d) Variation of normalized $V_{\mathrm{OC}}$ and $J_{\mathrm{SC}}$ for uncapsulated glass/ITO/PEDOT:PSS/P3HT:PCBM/LiF/Al as a function of time. (e) Variation of normalized $V_{\mathrm{OC}}$ and $J_{\mathrm{SC}}$ for uncapsulated glass/PEDOT:PSS/P3HT:PCBM/LiF/Al as a function of time. (f) Variation of normalized $V_{\mathrm{OC}}$ and $J_{\mathrm{SC}}$ for uncapsulated glass/ITO/P3HT:PCBM/LiF/Al as a function of time. (g) Change in $V_{\mathrm{OC}}$ with time for the devices. (h) Change in $J_{\mathrm{SC}}$ with time for the devices. The inset in the figure shows an enlarged view of the region where a change in polarity takes place. 
Table 1. $V_{\mathrm{OC}}$ and $J_{\mathrm{SC}}$ values for different structures as soon as they are fabricated and after degradation (up to $300 \mathrm{~h}$ ).

\begin{tabular}{|c|c|c|c|c|c|c|c|c|c|c|c|c|}
\hline \multirow[b]{2}{*}{$\begin{array}{l}\text { Time } \\
\text { (h) }\end{array}$} & \multicolumn{2}{|c|}{ S1 } & \multicolumn{2}{|c|}{ S2 } & \multicolumn{2}{|r|}{ S3 } & \multicolumn{2}{|r|}{ S4 } & \multicolumn{2}{|c|}{ S5 } & \multicolumn{2}{|c|}{ S6 } \\
\hline & $\begin{array}{l}V_{\mathrm{OC}} \\
(\mathrm{V})\end{array}$ & $\begin{array}{c}J_{\mathrm{SC}} \\
\left(\mathrm{A} \mathrm{cm}^{-2}\right)\end{array}$ & $\begin{array}{l}V_{\mathrm{OC}} \\
(\mathrm{V})\end{array}$ & $\begin{array}{c}J_{\mathrm{SC}} \\
\left(\mathrm{A} \mathrm{cm}^{-2}\right)\end{array}$ & $\begin{array}{l}V_{\mathrm{OC}} \\
(\mathrm{V})\end{array}$ & $\begin{array}{c}J_{\mathrm{SC}} \\
\left(\mathrm{A} \mathrm{cm}^{-2}\right)\end{array}$ & $\begin{array}{l}V_{\mathrm{OC}} \\
(\mathrm{V})\end{array}$ & $\begin{array}{c}J_{\mathrm{SC}} \\
\left(\mathrm{A} \mathrm{cm}^{-2}\right)\end{array}$ & $\begin{array}{l}V_{\mathrm{OC}} \\
(\mathrm{V})\end{array}$ & $\begin{array}{c}J_{\mathrm{SC}} \\
\left(\mathrm{A} \mathrm{cm}^{-2}\right)\end{array}$ & $\begin{array}{l}V_{\mathrm{OC}} \\
(\mathrm{V})\end{array}$ & $\begin{array}{c}J_{\mathrm{SC}} \\
\left(\mathrm{A} \mathrm{cm}^{-2}\right)\end{array}$ \\
\hline 0 & 0.289 & $-8.72 \mathrm{E}-4$ & 0.396 & $-3.05 E-7$ & 0.436 & $-8.97 \mathrm{E}-4$ & 0.476 & $-2.97 \mathrm{E}-3$ & 0.327 & $-4.86 \mathrm{E}-7$ & 0.503 & $-2.08 \mathrm{E}-3$ \\
\hline 4 & 0.316 & $-5.77 \mathrm{E}-4$ & 0.302 & $-2.32 \mathrm{E}-7$ & 0.409 & $-1.45 \mathrm{E}-6$ & 0.409 & $-6.96 \mathrm{E}-4$ & 0.383 & $-2.01 \mathrm{E}-7$ & 0.503 & $-1.66 \mathrm{E}-4$ \\
\hline 20 & 0.289 & $-1.22 \mathrm{E}-4$ & 0.302 & $-9.59 \mathrm{E}-8$ & 0.315 & $-6.41 \mathrm{E}-7$ & 0.235 & $-2.03 \mathrm{E}-5$ & 0.1 & $-9.14 \mathrm{E}-8$ & 0.182 & $1.79 \mathrm{E}-6$ \\
\hline 40 & 0.262 & $-3.23 \mathrm{E}-5$ & 0.141 & $-3.35 \mathrm{E}-9$ & -0.228 & $-2.74 \mathrm{E}-7$ & 0.0605 & $-2.20 \mathrm{E}-6$ & 0.107 & $-4.04 \mathrm{E}-8$ & -0.195 & $-3.44 \mathrm{E}-6$ \\
\hline 50 & 0.242 & $-2.87 \mathrm{E}-5$ & 0.107 & $-1.24 \mathrm{E}-7$ & -0.614 & $3.09 \mathrm{E}-7$ & 0.0401 & $-2.62 \mathrm{E}-6$ & 0.0739 & $-2.76 \mathrm{E}-8$ & -0.144 & $6.40 \mathrm{E}-7$ \\
\hline 120 & 0.141 & $-6.34 \mathrm{E}-6$ & -0.0204 & $9.35 \mathrm{E}-8$ & -0.597 & $3.47 \mathrm{E}-7$ & 0.0738 & $-1.38 \mathrm{E}-6$ & 0.00662 & $-5.28 \mathrm{E}-8$ & - & - \\
\hline 170 & 0.141 & $-1.75 \mathrm{E}-6$ & -0.0435 & $8.35 \mathrm{E}-8$ & -0.597 & $1.90 \mathrm{E}-7$ & -0.181 & $2.11 \mathrm{E}-6$ & -0.0096 & $1.85 \mathrm{E}-8$ & -0.275 & $1.40 \mathrm{E}-6$ \\
\hline 220 & 0.0570 & $-6.73 \mathrm{E}-8$ & -0.0236 & $7.10 \mathrm{E}-8$ & -0.631 & $2.82 \mathrm{E}-8$ & -0.278 & $3.27 \mathrm{E}-6$ & -0.0555 & $3.58 \mathrm{E}-8$ & -0.430 & $1.06 \mathrm{E}-6$ \\
\hline 290 & -0.279 & $6.05 \mathrm{E}-6$ & -0.312 & $1.74 \mathrm{E}-8$ & -0.748 & $6.75 \mathrm{E}-7$ & -0.212 & $3.44 \mathrm{E}-6$ & -0.228 & $4.04 \mathrm{E}-10$ & -0.832 & $4.67 \mathrm{E}-6$ \\
\hline
\end{tabular}

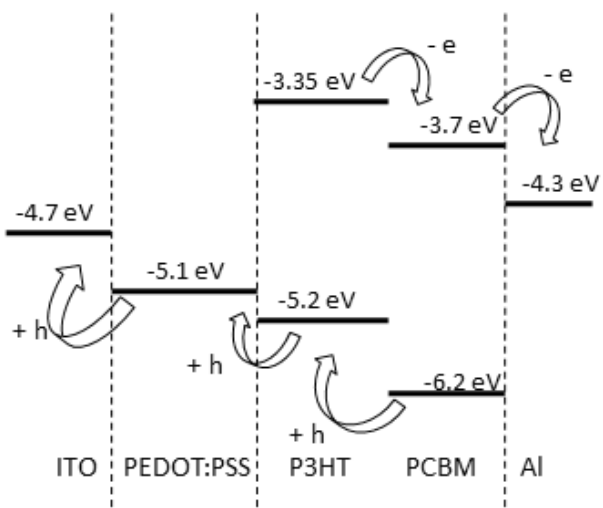

(a)

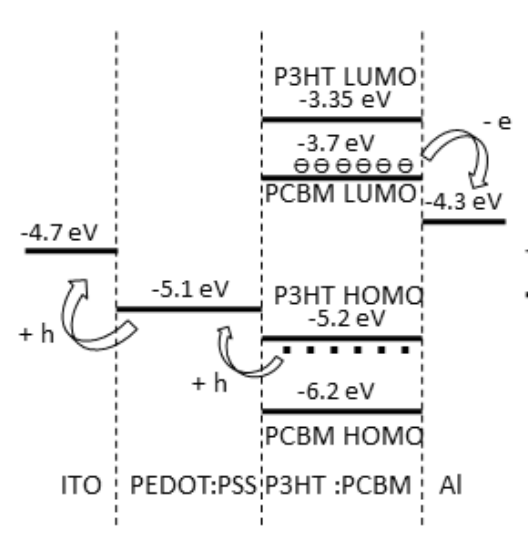

(b)

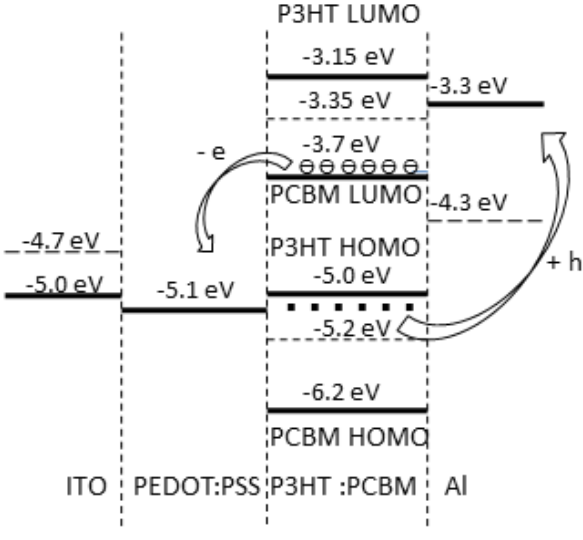

(c)

Figure 2. Band diagram of the P3HT:PCBM blend solar cell (a) as soon as it is fabricated, (b) after donor-acceptor domain formation and (c) proposed modified structure after degradation. In panel (c), dotted lines and solid lines represent the energy levels before degradation and after degradation, respectively.

because it helps holes to move. It may be pointed out that just before the change of polarity (where $V_{\mathrm{OC}} \approx 0$ ) there is an equal probability of collecting electrons and holes at the electrodes. In other words, the holes and electrons travel in both directions in the device. In the fresh device the interfaces and barriers at the interfaces enable the net current flow to be in one direction. Upon degradation this balance may tip and cause the net change in polarity as observed.

Attempts can be made to check the cell degradation once the dominant mechanism is known and effective measures can be taken such as proper encapsulation, improved morphology and good electrode contacts. Theoretical calculations are underway to explain the result quantitatively.

\section{Conclusion}

It can be concluded that the various degradation mechanisms are responsible for the decrease of $V_{\mathrm{OC}}$ and $J_{\mathrm{SC}}$, leading to a change in polarity with time as observed by us, and their net effect is to change the energy levels of the donor-acceptor composites and to shift the work functions (pseudo work function) of $\mathrm{Al}$ and ITO electrodes. With the passage of time a situation occurs that the direction of carrier collection probability reverses. This leads to a change of polarity of the organic solar cell. There is a need to control the interface states at the surface of the electrode by chemical modification, say by polar species, and shield the diffusion of impurities at the interfaces by adding a densely packed small molecule interlayer.

\section{Acknowledgments}

The authors thank DST Purse Grant, India for financial support. We also thank Professor P C Mathur, Department of Electronic Science, South Campus, University of Delhi and Dr M Aslam Parvaiz, Principal, Zakir Husain College, University of Delhi for valuable suggestions and support.

\section{References}

[1] Dennler G, Scharber M C and Brabec C J 2009 Adv. Mater 21 1323-38

[2] Lira-Cantu M, Chafiq A, Faissat J, Gonzalez-Valls I and Yu Y 2011 Sol. Energy Mater. Sol. Cells 95 1362-74

[3] Girtan M and Rusu M 2010 Sol. Energy Mater. Sol. Cells 94 446-50

[4] Cai W, Gong X and Cao Y 2010 Sol. Energy Mater. Sol. Cells 94 114-27

[5] Yang H B, Song Cheng Gong Q L and Li C M 2010 Sol. Energy Mater. Sol. Cells 94 846-9

[6] Kumar P, Jain S C, Kumar V, Chand S and Tandon R P 2009 Appl. Phys. A 94 281-6

[7] Jorgensen M, Norrman K and Krebs F C 2008 Sol. Energy Mater. Sol. Cells 92 686-714

[8] Morana M, Koers P, Waldauf C, Koppe M, Muehlbacher D, Denk P, Scharber M, Waller D and Brabec C 2007 Adv. Funct. Mater. 17 3274-83 
[9] Toyoshima S, Kuwabara K, Sakurai T, Taima T, Saito K, Kato H and Akimoto K 2007 Japan. J. Appl. Phys. 46 2692-5

[10] Bernede J C, Godoy A, Cattin L, Diaz F R, Morsli M and del Valle M A 2010 Solar Energy ed R D Rugescu (Rijeka: InTech) pp 223-61

[11] Street R A, Schoendorf M, Roy A and Lee J H 2010 Phys. Rev. B 81205307
[12] Arora S, Rajouria S K, Kumar P, Bhatnagar P K, Arora M and Tandon R P 2011 Phys. Scr. 83035804

[13] Cuiffi J, Benanti T, Nam W J and Fonash S 2010 Appl. Phys. Lett. 96143307

[14] Krebs F C and Norrman K 2007 Prog. Photovolt. 15 697-712

[15] Centurioni E and Iencinella D 2003 IEEE Electron Device Lett. 24 177-9 